\title{
EdUCAÇÃo PÚBLICA NAS METRÓPOLES BRASILEIRAS: IMPASSES E NOVOS DESENLACES
}

Educação pública nas metrópoles brasileiras: impasses e novos desenlaces; Organizadoras: Mônica G. T. do Amaral e Maria Cecília Cortez C. de Souza; Editora: Paco editorial/Edusp, 2011; No de páginas: 314; ISBN: 9788531413254.

$\mathrm{O}$ livro Educação pública nas metrópoles brasileiras: impasses e novos desenlaces apresenta um conjunto de artigos sobre preconceitos que persistem nas práticas educacionais contemporâneas, sobretudo nas grandes cidades como São Paulo e Rio de Janeiro. De outra parte, enfatiza como a teoria psicanalítica combinada com o método etnográfico, praticada em instituições educacionais, pode ser útil para a reconstrução de padrões de autoridade imprescindíveis ao ato educativo.

As metrópoles, em geral, demarcam aquelas áreas densas do tecido social em que as contradições, de toda ordem, deixam-se capturar somente pelo olhar atento daqueles que delas participam com certo distanciamento. As pesquisas etnográficas que se renovam nos espaços urbanos do nosso tempo conservaram uma visão aguçada, a fim de deslindar justamente aquilo que, dada sua premência, grita perante os ouvidos moucos e ao déficit de visão do homem comum, há muito embrutecido na árdua luta pela sobrevivência naqueles mesmos espaços, tão típicos das grandes cidades.

Em que pese a proliferação ingênua de certos "otimismos pedagógicos", em grande medida sintonizados com a expansão da grande indústria da cultura, cujo resíduo maior pode ser expresso pelo termo "massificação", isto é, achatamento sistemático das particularidades e aposta na planificação administrada das singularidades, atualmente parece não haver dúvidas quanto ao estado calamitoso da educação pública em nosso país. O livro Educação pública nas metrópoles brasileiras: impasses e novos desenlaces, organizado pelas coautoras Mônica G. T. do Amaral e Maria Cecília Cortez C. de Souza, revela não apenas o caótico cenário educacional público brasileiro, particularmente apreendido por meio de pesquisas realizadas em escolas da ca-

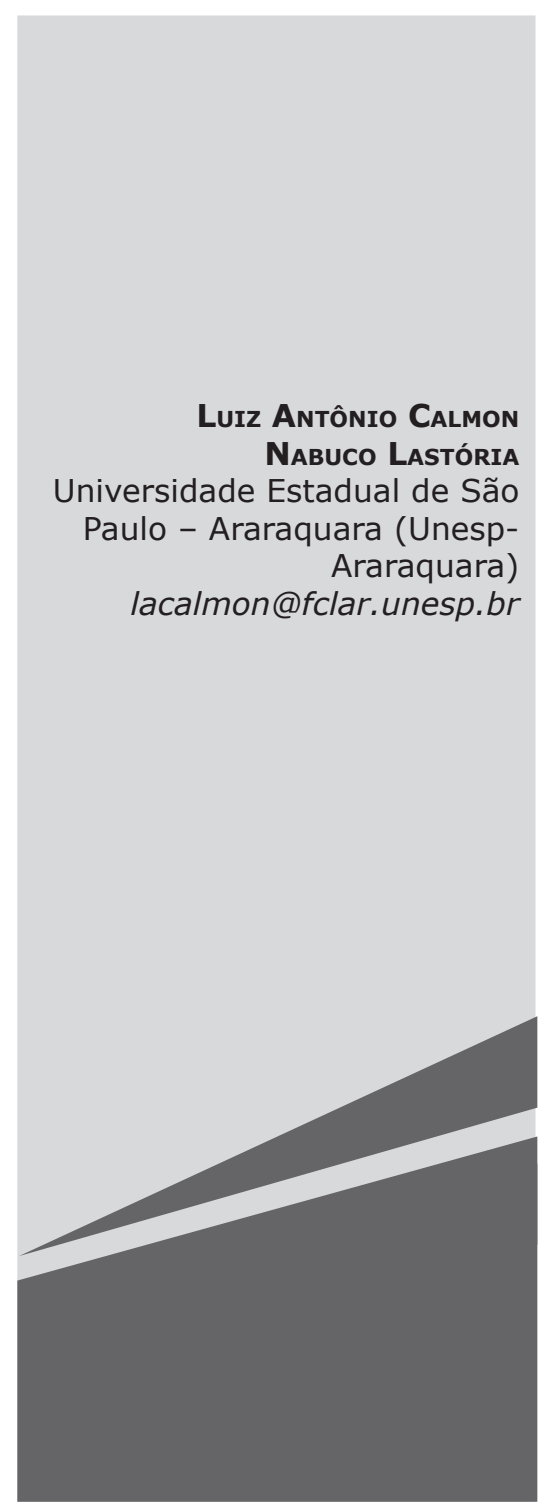


pital paulista, e em outra da cidade do Rio de Janeiro, mas também a possibilidade de "novos desenlaces". Sem perder o gume da crítica, o conjunto de artigos dispostos nas três partes constitutivas do livro ensaia uma profícua alternativa de diálogo entre o campo das práticas educativas e a teoria psicanalítica, sendo que alguns deles o fazem por meio de um peculiar entrecruzamento dessa teoria com o método etnográfico, tal como proposto por M. Canevacci.

O resultado obtido por meio do investimento teórico-prático presente nos artigos que compõem o livro aponta, tanto para a produção de uma particular escuta do universo semiológico próprio aos fenômenos culturais trazidos à cena pública por grupos de jovens postos à margem pelo sistema social (tal é o caso do funk e do movimento hip hop brasileiros), quanto para a conversão da práxis dessa escuta em ingrediente potencial capaz de promover, a um só tempo, a crítica dos padrões culturais hegemônicos, das políticas educacionais em vigência no País e das propostas que delas derivam para a ambiência escolar. E ainda, talvez o mais relevante, promover alterações significativas nas relações pedagógicas, sobretudo no que diz respeito aos processos dialógicos entre gerações, pautados por padrões de autoridade já claudicantes.

Se, no caso brasileiro, tais padrões foram historicamente engendrados a partir do ideário liberal republicano, matizado por relações étnicas que aqui se desenvolveram profundamente pautadas por práticas autoritárias, resta-nos a questão de saber em que medida - quando da passagem à universalização do capital sob a batuta de uma indústria cultural global - esses padrões podem ser reelaborados, ou mesmo reinventados, dada a tarefa civilizatória própria aos processos de escolarização. Cabe lembrar que, em tempos de aguda massificação, parafraseando W. Benjamin ao referir-se ao papel da crítica cultural, tratar-se-ia de defender o público, mesmo contra o público; observação essa que torna ainda mais intrincada a discussão entre os movimentos estéticos politicamente engajados e os mass media na contemporaneidade. Uma coisa, porém, parece-nos indubitável: ouvir as manifestações culturais juvenis e saber interpretá-las em um sentido favorável à emancipação constitui um ponto crucial para perpetuar, ou mesmo restabelecer, o tênue diálogo entre as gerações; diálogo sem o qual nenhuma educação será possível no horizonte que encerra nosso presente. O livro, que ora apresentamos ao leitor especializado, e também ao público em geral, testemunha essa convicção.

DADOS AUTORAIS:

\section{Luiz A. Calmon nabuco Lastória}

Professor doutor do Departamento de Psicologia da Educação da Faculdade de Ciências e Letras, Unesp-Araraquara, SP. Doutor em Psicologia pela Universidade de São Paulo-SP, pesquisador do Grupo de Estudos e Pesquisas "Teoria Crítica: Tecnologia, Cultura e formação” (CNPq). 